\title{
Introduction to the Special Issue Political Games: Strategy, Persuasion, and Learning
}

\author{
Gabriele Gratton ${ }^{1, *(\mathbb{D})}$ and Galina Zudenkova ${ }^{2}$ \\ 1 UNSW Business School, UNSW Sydney, Sydney, NSW 20152, Australia \\ 2 TU Dortmund University, D-44227 Dortmund, Germany; galina.zudenkova@tu-dortmund.de \\ * Correspondence: g.gratton@unsw.edu.au
}

Received: 26 January 2020; Accepted: 1 February 2020; Published: 7 February 2020

All political actors, from world leaders to common citizens, make choices based on information that is noisy, perhaps biased, and sometimes fake. In recent decades, widespread Internet use, the multiplication of specialized TV channels, and the rise of social media have fundamentally changed the way in which political actors collect and disseminate information. Political pundits and academics thus question whether common wisdom about media and political campaigns remains valid in this new environment of information and communication technologies (see, for example, [1-4]).

This Special Issue is a collection of articles that contribute to this debate, combining game-theoretical and experimental work. One piece of common wisdom is that electoral campaigns are swayed by public events such as endorsements by newspapers or celebrities. However, there is broad disagreement about why these public acts are particularly salient to voters. One theory is that voters believe that endorsements convey precise signals about key political issues debated during the campaign or about the relative quality of candidates. The opposing view is that these events serve as coordination devices for voters, independently of whether they are informative or not. Supporters of the latter view often point out that some salient events appear to be obviously uninformative.

In this Special Issue, Invernizzi [5] developed a clever series of experiments to test these two theories. Interestingly, she reports rather mixed evidence. In accordance with the first theory, the more informative the public signal is, the more the voters follow it. However, voters do not do so in the systematic way the theory would predict. In addition, voters' response is quite heterogeneous and therefore they fail to fully use the signal as a coordination device. Instead, the experiment reveals that what determines the voters' behavior in a homogeneous and significant way is the signal's recency. In all experiments in [5], almost every single subject follows the most recent signal with staggering regularity, regardless of the signal's precision. This finding raises new questions on the timing of information revelation in electoral campaigns, casting further concerns about manipulation of voting behavior (see, for example, [6,7]).

Bizzotto and Solow [8] dug deeper into the question of information manipulation during electoral campaigns. They noticed that campaigns are naturally multidimensional and that different voters care about different dimensions. In this context, the rise of social media and the availability of the individual data that come with it allow candidates to "microtarget" their campaign messages, i.e., to send different messages to different groups of voters. Bizzotto and Solow [8] found that such microtargeting is generically socially inefficient as it gives the candidates an incentive to commit to socially inefficient projects that benefit specific groups of voters. This result adds to the public debate on the role of social media in recent elections and may inform policymakers who wish to regulate individual data use for political campaigns (see, for example, [9]).

While political actors can manipulate or target information during electoral campaigns, electoral outcomes are solely determined by the voters' choices. Since the work of Austen-Smith and Banks [10], game-theoretical models have analyzed voting decisions in common value elections. The standard assumption in this literature is that voters are Bayesian expected utility maximizers. However, 
behavioral economics suggests that individuals behave very differently when they are uncertain about the information structure, i.e., when the environment is ambiguous. Recently, Ellis [11] extended the analysis of strategic voting in common value elections to ambiguous environments with ambiguity-averse voters. In this Special Issue, Pan [12] concisely provided a general description of such ambiguous voting games and derived general equilibrium conditions for them.

Deviations from rationality are also often considered as possible causes for Pareto inefficient conflicts. In particular, one oft-cited explanation for conflict is that players are mutually optimistic, i.e., each side expects to prevail in the ensuing conflict. However, why would world leaders have such inconsistent beliefs? In this Special Issue, Serena [13] developed the idea that such beliefs are formed as a result of a particular form of information naivety when players systematically fail to draw correct inference about each other's private information from each other's action. To put it bluntly, when the two sides do not "read" into each other's actions, then mutual optimism is a natural result, thus leading to Pareto inefficient conflicts.

In conclusion, the four articles in this Special Issue contribute to our understanding of the role of information structure and belief formation in political games. The articles promote novel ideas and address understudied questions, which range from salience determination to microtargeting, ambiguous voting, and information naivety. The findings complement the existing literature and suggest rationales for inefficiencies that arise in political environments with incomplete and noisy information.

Conflicts of Interest: The authors declare no conflict of interest.

\section{References}

1. Allcott, H.; Gentzkow, M. Social Media and Fake News in the 2016 Election. J. Econ. Perspect. 2017, 31, 211-236. [CrossRef]

2. Gentzkow, M.; Shapiro, J.M. Ideological Segregation Online and Offline. Q. J. Econ. 2011, 126, 1799-1839. [CrossRef]

3. Townsend, T. The Bizarre Truth Behind the Biggest Pro-Trump Facebook Hoaxes. Inc., 21 November 2016.

4. Wingfield, N.; Isaac, M.; Benner, K. Google and Facebook Take Aim at Fake News Sites. New York Times, 14 November 2016.

5. Invernizzi, G.M. Public Information: Relevance or Salience? Games 2020, 11, 4. [CrossRef]

6. Guttman, I.; Kremer, I.; Skrzypacz, A. Not Only What but Also When: A Theory of Dynamic Voluntary Disclosure. Am. Econ. Rev. 2014, 104, 2400-2420. [CrossRef]

7. Gratton, G.; Holden, R.; Kolotilin, A. When to Drop a Bombshell. Rev. Econ. Stud. 2018, 85, 2139-2172. [CrossRef]

8. Bizzotto, J.; Solow, B. Electoral Competition with Strategic Disclosure. Games 2019, 10, 29. [CrossRef]

9. Aral, S.; Eckles, D. Protecting Elections from Social Media Manipulation. Science 2019, 365, 858-861. [CrossRef] [PubMed]

10. Austen-Smith, D.; Banks, J.S. Information Aggregation, Rationality, and the Condorcet Jury Theorem. Am. Political Sci. Rev. 1996, 90, 34-45. [CrossRef]

11. Ellis, A. Condorcet Meets Ellsberg. Theor. Econ. 2016, 11, 865-895. [CrossRef]

12. Pan, A. A Note on Pivotality. Games 2019, 10, 24. [CrossRef]

13. Serena, M. A Game-Free Microfoundation of Mutual Optimism. Games 2019, 10, 37. [CrossRef]

(c) 2020 by the authors. Licensee MDPI, Basel, Switzerland. This article is an open access article distributed under the terms and conditions of the Creative Commons Attribution (CC BY) license (http://creativecommons.org/licenses/by/4.0/). 